\title{
Spatial and Temporal Dynamics of Water Quality in Batticaloa Lagoon in Sri Lanka
}

\author{
M. Sugirtharan*, S. Pathmarajah ${ }^{1}$ and M.I.M. Mowjood ${ }^{1}$ \\ Postgraduate Institute of Agriculture \\ University of Peradeniya \\ Sri Lanka
}

\begin{abstract}
The present study was undertaken to characterise the spatial and temporal dynamics of physico-chemical parameters of the Batticaloa Lagoon in Sri Lanka during November 2012 to October 2013. Eighteen sampling locations were clustered based on their positions from the Palameenmadu bar mouth. Physico-chemical parameters like temperature, electrical conductivity (EC), total dissolved solids (TDS), pH, salinity, dissolved oxygen (DO), turbidity, nitrate, phosphate and total suspended solids (TSS) were measured $15-30 \mathrm{~cm}$ below the water surface. The study revealed that the water temperature of the lagoon varied between 26.1-33.6 ${ }^{\circ} \mathrm{C}$; EC 0.24-36.6 dS $/ \mathrm{m}$; TDS 0.1-18.3 ppt; pH 7.328.87; salinity 1.6-34 ppt; DO 3.98-11.98 mg/l; turbidity 3-41 FAU; nitrate 0.8-8.3 mg/l; phosphate 0.04-1.56 mg/l and TSS 562-6021 mg/l. High values of salinity were observed in the lagoon water near the barmouth, and during the dry months. Rainfall and the distance from sea play a major role in the variation of salinity of the lagoon. Decreasing trend in salinity was observed from the distance from barmouth to the West, North and Southern part of the lagoon. High nutrient concentration at the lagoon was observed in the locations near to the farms and cultivation areas. The water quality parameters are favourable to the production of brackish water fish and prawns during dry months. However, it contains high salt and suspended particles, thus not suitable for drinking. The results are important in understanding the pattern of variation of water quality parameters so as to assist relevant agencies to plan, protect and aid in the management of the lagoon water for different uses.
\end{abstract}

Keywords: Batticaloa Lagoon, dissolved oxygen, nutrients, salinity, water quality.

\section{INTRODUCTION}

Coastal lagoons occupy $13 \%$ of worldwide coastal areas and are often subjected to both natural and man-made changes. They have become major sites for extensive and diverse economic activities such as fishing, tourism development, aquaculture industry etc. (Sikora and Kjerfve, 1985). Batticaloa Lagoon is one of the estuarine lagoons situated in the East Coast of Sri Lanka. It is the largest coastal water body in the District and occupies an area of $168 \mathrm{~km}^{2}$ (Green Tech Consultants, 2009). This Lagoon is $56 \mathrm{~km}$ long and extends from Kittangi/ Kalmunai in Ampara District in the south to Pankudaweli in Batticaloa District in the north. The lagoon is surrounded by a densely populated area used for cultivation of rice, coconut and other crops. The surrounding land is also used for shrimp farming. The lagoon

\footnotetext{
${ }^{1}$ Department of Agricultural Engineering, Faculty of Agriculture, University of Peradeniya, Sri Lanka

* Corresponding author: sugirtharan818@yahoo.com
} 
has extensive mangrove swamps and some sea grass beds. Most of the fishing community is dependent on this lagoon for their livelihood. This lagoon opens into the sea at two points; one in the southern end of the lagoon at Kallar and the other is midway of the lagoon at Palameenmadu which is close to the Batticaloa town. Palameenmadu barmouth is generally open most of the time but the other barmouth is usually open only during rainy seasons.

This lagoon suffers from anthropogenic activities in the surroundings. The impacts would be further aggravated by the effects of climate change events such as extreme floods and droughts, sea level rise and subsequent sea water intrusion. One of the most pressing threats to estuaries is diminishing water quality as a consequence of urban growth and land use that increases the impervious surface area and non-point source runoff of nutrients and sediment (Choi and Blood, 1999; James, 2001). Non-point sources in residential development areas can have larger negative impacts on water quality than urban point sources (Atasoy et al., 2006). All these factors will finally affect the lagoon water quality and its uses. Therefore, water quality monitoring is a fundamental tool in the management of lagoons. In this view, the present study was conducted with the aim of characterising spatial and temporal dynamics of physico-chemical parameters of the Batticaloa Lagoon over a period of one year as an important step to prepare the management plan against its effect on dependent economic activities such as fishing, tourism, irrigation and aquaculture industry like prawn farm and crab culture.

\section{METHODOLOGY}

\section{Description of the study site}

Batticaloa Lagoon which is located between $7^{\circ} 24^{\prime}-7^{\circ} 46^{\prime} \mathrm{N}$, and $81^{\circ} 35^{\prime}-81^{\circ} 49^{\prime} \mathrm{E}$, is one of the most productive brackish water bodies in Sri Lanka (Fig. 1). Slightly elevated areas within the Batticaloa Lagoon form islands.

\section{Sampling locations}

The sampling locations were clustered and grouped into three (A1, A2 and A3) based on their positions from the Palameenmadu barmoth (Fig. 1). Accordingly, certain locations (L1, L2 and L3) fall into more than one group based on the direction of analysis.

A1 (Barmouth to West part of the lagoon)

A2 (Barmouth to Northern end of lagoon)

A3 (Barmouth to Southern end of the lagoon)
- L1, L2, L3, L5, L6

- L1, L2, L3, L4, L7, L8, L9

- L1, L2, L10, L11, L12, L13, L14, L15, L16, L17, L18 


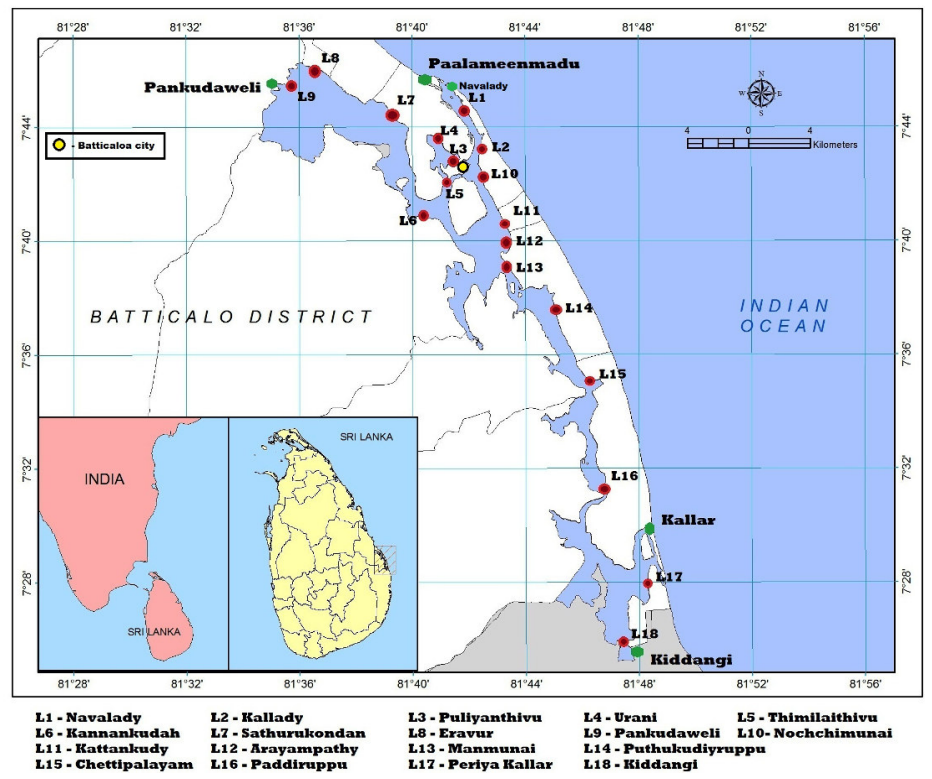

Fig. 1. Map of the study area and the sampling locations

\section{Sample collection}

Water samples were collected at 18 different locations along the coast of the lagoon. The locations (Fig. 1) of the sampling points were positioned using a hand held GPS. The distance between each sampling location varied approximately within 1-5 km. As the lagoon extends over $56 \mathrm{~km}$, the sample collection and field measurements were done within three consecutive days. Sample collection was done using a canoe to reach the points of sampling. Sampling cans of one litre were rinsed with lagoon water at each location prior to sampling. The surface water samples between the depths of $15-30 \mathrm{~cm}$ were collected once a month for a period of one year from November 2012 to October 2013. The period covered dry and wet seasons of the year, and the period during which the barmouth mostly opens to sea (from January to August) and the period at which the lagoon mouth is closed (September to December). Three samples were collected at each point and the mean value was taken for data analysis.

In-situ field measurements were taken for temperature, Electrical Conductivity (EC), Total Dissolved Solids (TDS) and $\mathrm{pH}$ using digital $\mathrm{pH} / \mathrm{EC} / \mathrm{TDS}$ meter (HANNA-Model HI 98130), salinity using Master Refractrometer (ATAGO, Japan) and Dissolved Oxygen by using a DO meter (HANNA-Model HI 8043). Total Suspended Solids (TSS) was measured by oven dry method at $105{ }^{\circ} \mathrm{C}$ (APHA, 1995). Other parameters measured were, turbidity (Formazin Attenuation Units - FAU by Attenuated radiation method no.8237), nitrate (Cadmium reduction method - 8039) and total phosphate (Phos Ver3 method-8048) using HACH 2010 spectrophotometer (USA). Instruments used for these analyses were calibrated before use at the water quality lab of the Department of Agricultural Engineering, Eastern University, Sri Lanka. 
The data collected in the field were analysed for descriptive statistics and relationship between water quality parameters (Pearson correlation) using Minitab 14 statistical software package.

\section{RESULTS AND DISCUSSION}

\section{Temperature variations in lagoon}

Water temperature is one of the most important environmental variables and a limiting factor in the aquatic environment. It affects metabolic activities, growth, feeding, reproduction, distribution and migratory behaviours of aquatic organisms (Suski et al, 2006). Mean temperature of the lagoon ranges from $28.3{ }^{\circ} \mathrm{C}$ to $32.0{ }^{\circ} \mathrm{C}$ during the twelve month sampling period (Table 1) the lowest temperature $\left(26.1{ }^{\circ} \mathrm{C}\right.$ ) was observed in March 2013 at Kattankudy (L11) and highest temperature of $33.6{ }^{\circ} \mathrm{C}$ was observed at Sathurukondan (L7) during May 2013. The slight variations were due to different times of sampling and the variation in the atmospheric temperature during day and night and the wind action within the lagoon environment. Temperature of lagoon was high (above $33{ }^{\circ} \mathrm{C}$ ) during the period of April 2013 to August 2013. These values were within the acceptable levels for survival, metabolism and physiology of aquatic organisms. However, according to Kara et al., (2004), temperature over $30{ }^{\circ} \mathrm{C}$ can cause regression in growth and decay in plants at water environment. Levels of correlations among water quality parameters are shown in Table 2. Accordingly, temperature of the lagoon has negative influence $\left(\mathrm{r}=-0.256^{* *}\right)$ on dissolved oxygen content of the lagoon water. 
Table 1. Mean values of the water quality parameters of the Batticaloa Lagoon

\begin{tabular}{|c|c|c|c|c|c|c|c|c|c|c|}
\hline $\begin{array}{c}\text { Sampling } \\
\text { period }\end{array}$ & $\begin{array}{l}\text { Temp } \\
\left({ }^{\circ} \mathrm{C}\right)\end{array}$ & $\begin{array}{c}\mathrm{EC} \\
(\mathrm{dS} / \mathrm{m})\end{array}$ & $\begin{array}{l}\text { TDS } \\
(\mathrm{ppt})\end{array}$ & $\mathrm{pH}$ & $\begin{array}{l}\text { Salinity } \\
\text { (ppt) }\end{array}$ & $\begin{array}{c}\mathrm{DO} \\
(\mathrm{mg} / \mathrm{l})\end{array}$ & $\begin{array}{l}\text { TSS } \\
(\mathrm{mg} / \mathrm{l})\end{array}$ & $\begin{array}{l}\text { Turbidity } \\
\text { (FAU) }\end{array}$ & $\begin{array}{c}\text { Nitrate } \\
(\mathrm{mg} / \mathrm{l})\end{array}$ & $\begin{array}{l}\text { Phosphate } \\
(\mathrm{mg} / \mathrm{l})\end{array}$ \\
\hline 12-Nov & 29.7 & 13.62 & 6.81 & 7.76 & 12.39 & 6.2 & 2229 & 13 & 3.16 & 0.40 \\
\hline 12-Dec & 29.5 & 4.32 & 2.16 & 8.00 & 4.74 & 5.9 & 3420 & 22 & 3.03 & 0.45 \\
\hline 13-Jan & 28.4 & 3.12 & 1.56 & 8.20 & 3.64 & 6.4 & 3575 & 25 & 2.81 & 0.38 \\
\hline 13-Feb & 28.3 & 1.80 & 0.90 & 8.24 & 3.43 & 7.3 & 2092 & 20 & 2.57 & 0.22 \\
\hline 13-Mar & 29.0 & 10.12 & 5.06 & 8.29 & 9.28 & 7.2 & 2070 & 18 & 2.12 & 0.21 \\
\hline 13-Apr & 31.3 & 14.00 & 7.00 & 8.24 & 12.54 & 6.7 & 2020 & 14 & 2.22 & 0.20 \\
\hline 13-May & 30.9 & 14.61 & 7.31 & 8.44 & 13.62 & 7.1 & 1852 & 12 & 2.26 & 0.25 \\
\hline 13-Jun & 31.3 & 15.77 & 7.88 & 8.39 & 14.66 & 6.9 & 1888 & 13 & 2.29 & 0.19 \\
\hline 13-Jul & 32.0 & 16.76 & 8.38 & 7.85 & 15.47 & 7.3 & 2373 & 13 & 2.72 & 0.18 \\
\hline 13-Aug & 31.3 & 17.43 & 8.71 & 7.93 & 16.07 & 5.9 & 3294 & 25 & 2.49 & 0.28 \\
\hline 13-Sep & 31.4 & 18.33 & 9.16 & 7.92 & 17.16 & 6.6 & 2012 & 17 & 2.21 & 0.27 \\
\hline $13-\mathrm{Oct}$ & 31.4 & 20.42 & 10.21 & 7.91 & 19.14 & 7.6 & 1225 & 10 & 2.46 & 0.50 \\
\hline
\end{tabular}




\section{Spatial and temporal variations in Electrical Conductivity (EC), Total Dissolved Solid (TDS) and salinity}

The EC and TDS of the Batticaloa Lagoon fall within $0.24 \mathrm{dS} / \mathrm{m}$ to $36.6 \mathrm{dS} / \mathrm{m}$ and $0.1 \mathrm{ppt}$ to $18.3 \mathrm{ppt}$, respectively. Lowest value of EC $(0.24 \mathrm{dS} / \mathrm{m})$ and TDS $(0.1 \mathrm{ppt})$ was recorded at Manmunai area (L13) during February 2013 and the highest EC (36.6 dS/m) and TDS (18.3 ppt) were observed during October 2013 at Navalady (L1) which is very closer to the sea outlet than the other locations. High TDS values are the indication of water in the Batticaloa Lagoon as brackish in nature.

The IJnited States Fnvirnnmental Protection Aoency (IISFPA) Secondarv Reoulations advise a maximum contamination level (MCI.) of $500 \mathrm{mo} / 1$ (0 $5 \mathrm{nnt}$ ) for TDS When TDS levels exceed $1000 \mathrm{mg} / \mathrm{l}(1 \mathrm{ppt})$ it is generally considered unfit for human consumption. Present study revealed that TDS concentrations exceed the desirable limit of $1 \mathrm{ppt}$ in most of the times except in some locations during the months of January to February. Though, lagoon water is not used for domestic water supply, it could have some influence on the groundwater of the surrounding areas.

Salinity is a dynamic indicator of the nature of the exchange system. It is expressed as the total concentration of electrically charged ions (cations) in water. It determines distribution of organisms in aquatic environments (Lawson, 2011). Spatial and temporal variability of salinity in the lagoon from the barmouth in west, north and south directions are shown in Fig. 2.

Salinity level was the highest (34 ppt) during the month of October 2013 at Navalady (L1) which is located very closer to the barmouth opening. Decreasing trend in salinity values were observed from the distance from barmouth to the West, North and Southern part of the lagoon. Comparatively higher values of salinity were observed at area A1 because of the closer distance from the barmouth (Figure 2a). Increasing trend of salinity at Periyakallar (L17) was found during January 2013 to March 2013 and then decreasing from March 2013 (Figure 2c). It could have been due to the opening of Kallar barmouth. Further, higher salinity values are recorded during dry months (April to October 2013) than wet months (November to January). Salinity decreased drastically with the onset of rainfall in all the locations during the wet months due to pushing effect from direct rainfall and runoff inflow towards the sea. It is evident that salinity of the lagoon is highly influenced with rainfall in the study area. While comparing the previous studies on salinity of the lagoons in Sri Lanka, Batticaloa Lagoon showed higher salinity levels than Koggala Lagoon (Furusato et al., 2012) and Negombo Lagoon (Chandrasekara et al., 2014). This higher values may be due to the prolong period of barmouth opening in Batticaloa. 

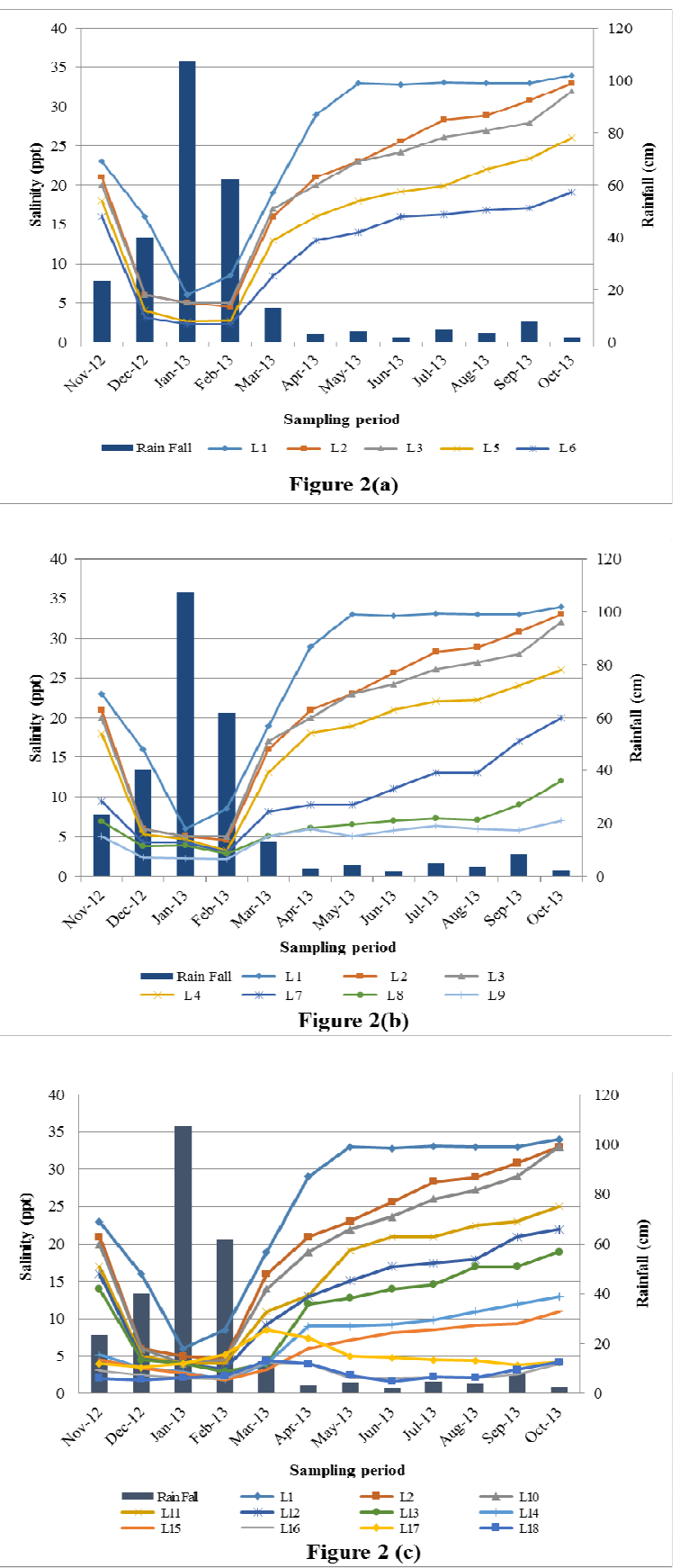

Fig. 2. Spatial and temporal variation of salinity of the Batticaloa Lagoon (a, b and $c$ are for West, North and South directions, respectively)

The salinity of the Batticaloa Lagoon water clearly shows the occurrence of sea water intrusion through the barmouth. Similarly, Furusato et al., (2012) also reported that in Koggala Lagoon, temporal and spatial complexities of lagoon mouth affect transport and 
mixing of saline water and intrusion into the lagoon. Salinity level of 4 to $25 \mathrm{ppt}$ is the tolerable range for most of the prawn species (Banerjee, 2008). Therefore, mixing of seawater favours the growth of prawn in the lagoon during February to June. However, it could affect the paddy cultivation near the lagoon. As far as the relationship between salinity of the Batticaloa Lagoon and rainfall amount is concerned, Sugirtharan et al., (2014a) reported that, salinity showed a highly significant decreasing trend with time $(\mathrm{r}=-0.693)$ during the rainy season whereas, non-significant negative correlation was found between rainfall amount and the salinity during dry season (2014b). Similarly, a significant positive correlation was observed between the rainfall amount and the lagoon water height $(\mathrm{r}=0.782)$. Salinity showed non-significant correlation with lagoon water height and the amount of rainfall.

\section{Spatial and temporal variations in $\mathrm{pH}$}

Hydrogen ion concentration or $\mathrm{pH}$ is one of the vital environmental characteristics decides the survival, metabolism, physiology and growth of aquatic organisms (Lawson, 2011). Variation of $\mathrm{pH}$ at 18 different locations during twelve sampling occasions shows that the highest $\mathrm{pH}$ (8.87) was observed at Sathurukondan (L7) during May 2013 whereas, the lowest $\mathrm{pH}$ (7.32) was recorded at Kiddangi (L18) during July 2013. The $\mathrm{pH}$ values varied at different locations. Lawson (2011) further explained that the $\mathrm{pH}$ is usually influenced by the characteristics of bottom sediment, microbial activities and photosynthesis by dense phytoplankton blooms and it may also be affected by total alkalinity and acidity and runoff water from surrounding land. According to Abowei (2010), $\mathrm{pH}$ higher than 7.0 but lower than 8.5 is ideal for biological productivity, but $\mathrm{pH}<4$ is detrimental to aquatic life. Present study results show that the mean $\mathrm{pH}$ of lagoon lies within the range of 7.76 to 8.44 during twelve months sampling period which is suitable for aquatic life. It also falls within the WHO (2008) standards of $6.5-8.5$, for the surface water based on the aesthetic considerations. However, $\mathrm{pH}$ values reached up to 8.87 in some locations may be due to the inflow of drainage water from the paddy land to that particular location during the time of sample collection, however, the exact reason for the fluctuation of these $\mathrm{pH}$ values couldn't be identified.

\section{Spatial and temporal variation in Dissolved Oxygen (DO)}

Mean values of DO concentration of the samples collected in all locations in the Batticaloa Lagoon during study period ranged from $5.9 \mathrm{mg} / 1$ to $7.6 \mathrm{mg} / 1$ (Table 1). Fig. 3 illustrates the fluctuation of DO levels in different locations during the period of one year. 

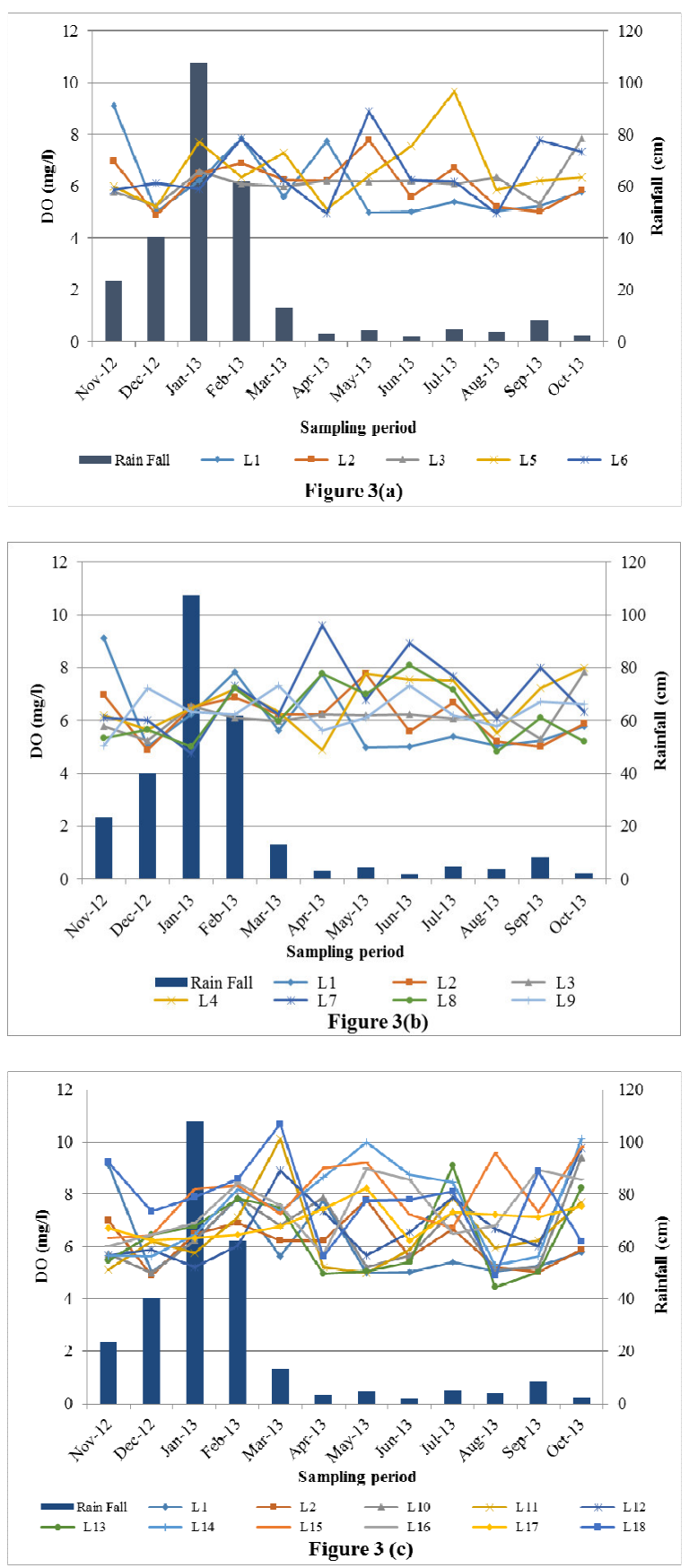

Fig. 3. Spatial and temporal variation of DO concentration in Batticaloa Lagoon (a, b and $\mathrm{c}$ are for West, North and South directions, respectively)

Lower level of DO (4.45 mg/l) was recorded at Manmunai (L13) whereas, highest DO (10.7 $\mathrm{mg} / \mathrm{l}$ ) values were obtained at Kiddangi (L18). Fig. 3 shows that there was no any spatial relationship with the increasing distance from barmouth. The increase in turbulence of the 
lagoon was observed during sample collections in the months of July and August. That might have increase DO concentration in most of the locations during those periods. DO concentrations were fluctuating during the sample collection period. The TDS, salinity and temperature might have influenced on the change of DO in water at different locations. As far as the dissolved oxygen of the Batticaloa Lagoon is concerned, the present study revealed that there was a significant negative correlation found (Table 2$)$ with salinity $\left(\mathrm{r}=-0.186^{* *}\right)$, temperature $\left(\mathrm{r}=-0.256^{* *}\right)$ and TSS $\left(\mathrm{r}=-0.594^{* *}\right)$. Srinivasan and Natesan $(2013)$ also found similar results in Muttukadu Backwaters in Tamilnadu.

NECCDEP (2010) reported that fish kills are periodically reported from the Batticaloa Lagoon due to the low DO levels of the lagoon in some seasons. If DO levels drop below 3.9 $\mathrm{mg} / \mathrm{l}$ some fish and other aquatic organism can be stressed and if it drops below $2.0 \mathrm{mg} / \mathrm{l}$ many species can die off. The location Manmunai (L13) identified as DO stressed area during August 2013. DO also affects the solubility and availability of nutrients. The variation in DO level might influenced by the presence of water weeds and their decayed plant materials, domestic waste and human/animal waste found their ways into the lagoon. Garnier et al., (2000) also reported that, in aquatic systems, oxygenation is the result of an imbalance between the process of photosynthesis, degradation of organic matter, re aeration and the physico-chemical properties of water. Low DO content of lagoon water during dry months might have caused by high salinity level of the lagoon water, because, DO level in waters depend on water temperature, partial pressure of oxygen in atmosphere and salt contents in waters Lawson (2011).

\section{Spatial and temporal variations in Total Suspended Solids (TSS) and turbidity}

Fig. 4 illustrates the monthly fluctuation of TSS in Batticaloa Lagoon at different locations. Highest TSS $(6021 \mathrm{mg} / \mathrm{l})$ was recorded during January 2013 at Sathurukondan (L7). Generally TSS concentration of Batticaloa Lagoon is high during rainy season (December 2012 and January 2013) and in the month of August. A high load of suspended solids with runoff water from surrounding area enters into the lagoon during heavy rainy days. And the heavy wind action (Kachchaan) during the July and August month might have increased the tidal action of lagoon thus increasing the turbidity. There is no noticeable seasonal trend in turbidity observed.

The present study revealed that, there was a significant negative correlation $(\mathrm{r}=-0.594 * *)$ found in between DO and TSS (Table 2). High concentrations of suspended solids can lower the photosynthetic rate of the aquatic plants by blocking the light penetration into the water body thus reduce the oxygen necessary for aquatic life. Lawson (2011) reported that, total suspended solids are products of runoffs. TSS increase with increased rainfall and have adverse effects on dissolved oxygen and carbon dioxide, and affect metabolism and physiology of fish and other aquatic organisms. Bilotta and Brazier (2008) also mentioned that, high TSS concentration could cause a reduced development and survival of fish eggs and larvae. Clogging of TSS on fish gills could also result into stress, reduced growth, suppressed-immune system leading to increased susceptibility to disease and osmotic dysfunction and death. Source of total suspended solids include erosion from urban runoff and agricultural land, industrial wastes, bank erosion and algae growth. 

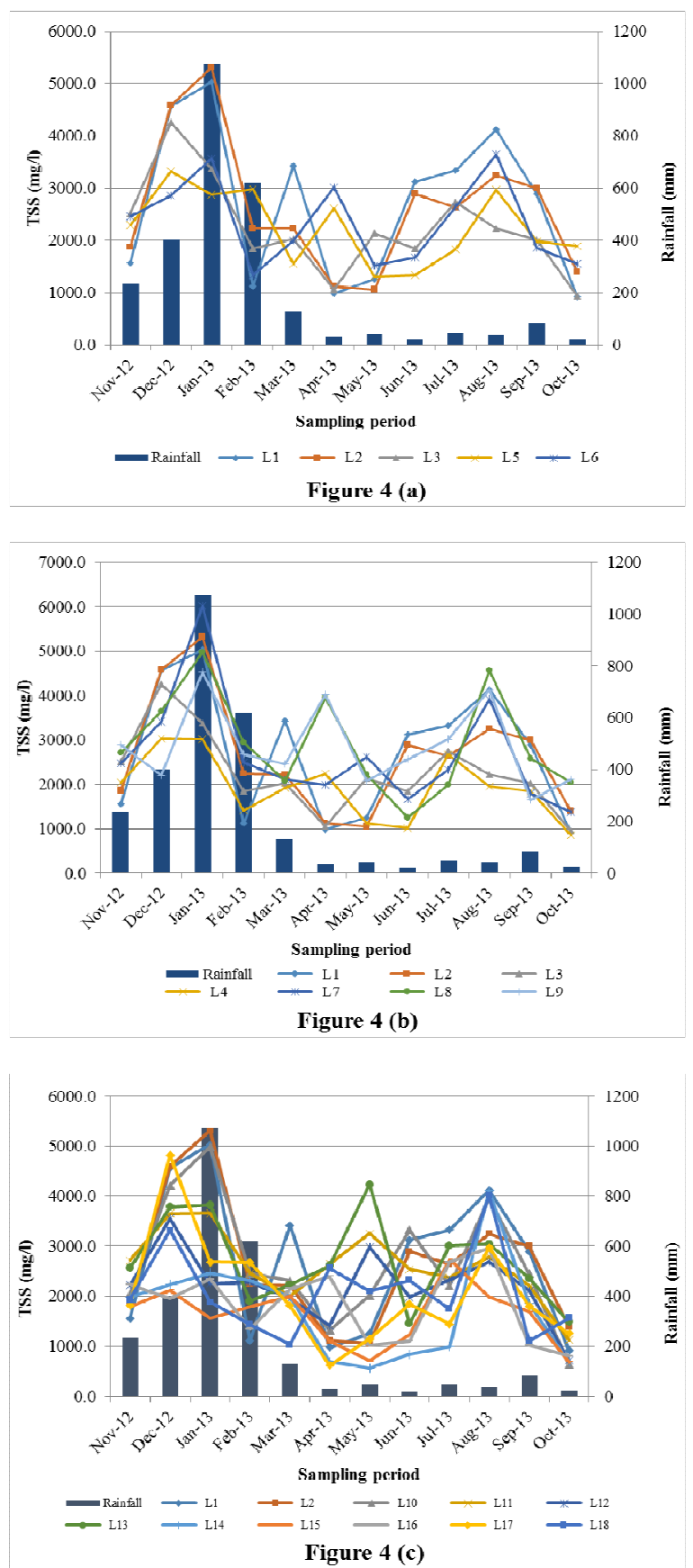

Fig. 4. Spatial and temporal variations of TSS in Batticaloa Lagoon ( $a, b$ and $c$ are for west north and south directions, respectively)

The minimum value of turbidity (3 FAU) was recorded at Puthukudiyruppu (L14) and Chettipalayam (L15) during the latter part of dry season (October) whereas, maximum turbidity values (41 FAU) was recorded at Sathurukondan (L7) during January 2013 where 
the lagoon act as a reservoir for the excess drainage water from the urban and agricultural areas.

The mean values of turbidity ranged from 10 to 25 FAU (Table 1). Highest mean value was recorded during January 2013 where high runoff water accumulated with high inputs of suspended particles into the lagoon due to the heavy rainfall. Opening of sluice gate of Unnichchai major irrigation tank to drain the excess rain water also carries sediments from upper catchment area to the lagoon. It is also found that turbidity of the lagoon water exceeds the maximum threshold limits (22 FAU) for aquatic life during rainy season as well as in the months of July and August where heavy wind was experienced.

Table 2. Pearson correlation (r) among water quality parameters of the Batticaloa Lagoon

\begin{tabular}{llllllll}
\hline $\begin{array}{l}\text { Water } \\
\text { quality } \\
\text { parameter }\end{array}$ & Temp & DO & $\mathbf{p H}$ & salinity & TSS & $\mathbf{N O}_{3}{ }^{-}$ & $\mathbf{P O}_{4}{ }^{3-}$ \\
Temp & 1 & & & & & & \\
DO & - & & & & & & \\
pH & $-56 * *$ & 1 & & & & & \\
Salinity & $-.157^{*}$ & -0.09 & 1 & & & & \\
$\mathrm{TSS}^{-373 * *}$ & $-.186^{* *}$ & $.218^{* *}$ & 1 & & & \\
$\mathrm{NO}_{3}{ }^{-}$ & -0.015 & $-.594 * *$ & 0.035 & $-.150^{*}$ & 1 & \\
$\mathrm{PO}_{4}{ }^{3-}$ & -0.121 & 0.01 & -0.031 & -0.1 & 0.096 & 1 & \\
\hline
\end{tabular}

**. Correlation is significant at the 0.01 level (2-tailed).

*. Correlation is significant at the 0.05 level (2-tailed).

\section{Spatial and temporal variations in nitrate}

The mean nitrate concentration ranged from $2.12 \mathrm{mg} / 1$ to $3.16 \mathrm{mg} / \mathrm{l}$ (Table 1). Higher nitrate levels $(8.3 \mathrm{mg} / \mathrm{l})$ were recorded during December 2012 at Manmunai (L13) area (Fig. 5). Drainage water from paddy field and the mixing of prawn farm effluents with lagoon water during the rainy periods might have caused high nitrate levels in that area. Higher nitrate concentrations in lagoon water were found near cultivated lands and where the drainage water from nearby lands enters into the lagoon. 

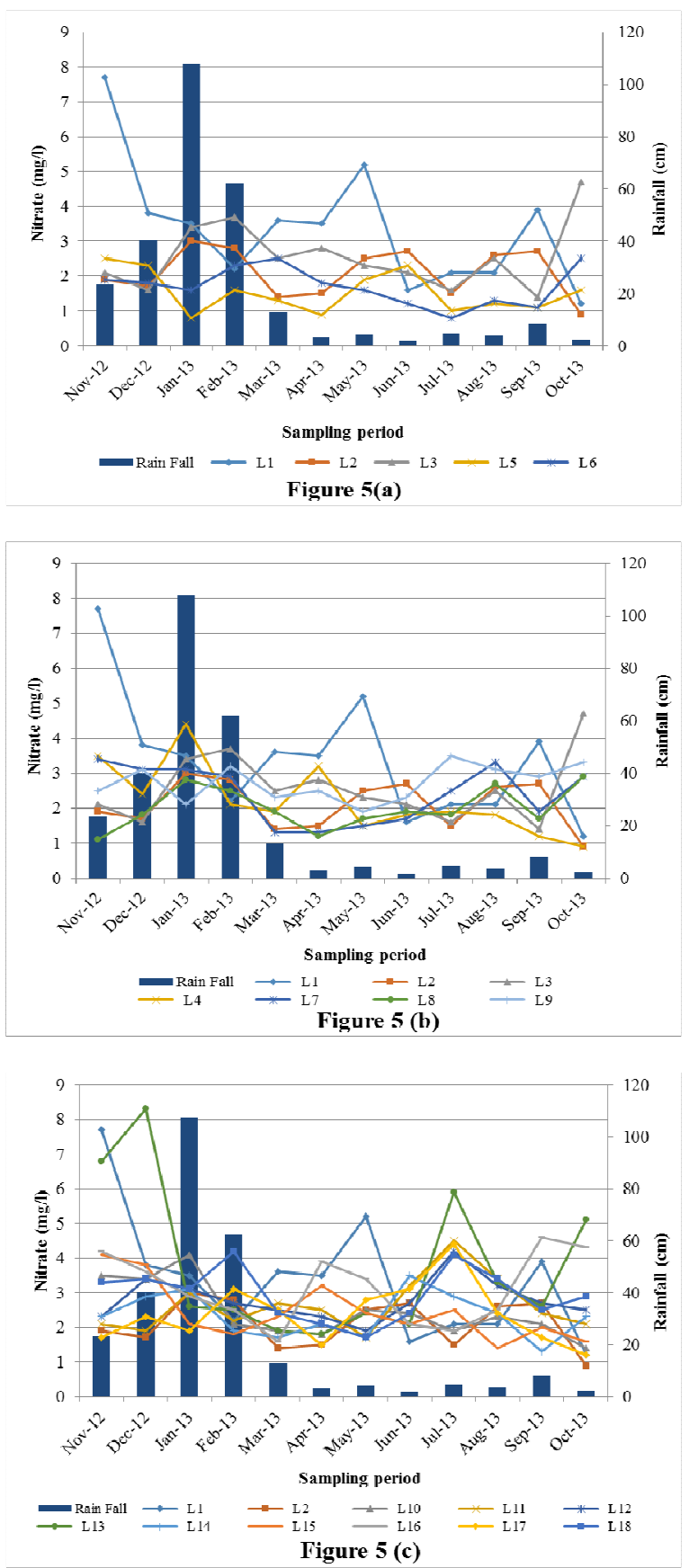

Fig. 5. Spatial and temporal variations of nitrate concentrations in Batticaloa Lagoon (a, $b$ and $c$ are for west north and south directions, respectively)

According to the Central Environment Authority (CEA) water quality standards for Sri Lanka as quoted by Green Tech Consultants (2009), the threshold value of nitrates for aquatic species is $5 \mathrm{mg} / \mathrm{l}$. In some locations of the Batticaloa Lagoon nitrate levels exceeded this limit. This may lead to eutrophication and algal blooming in particular, places where 
water stagnated for a longer period. This condition was observed during the field visits in many places such as Puthur, Urani, Thimilatheevu, Kannankuda, Puliyantheevu, Kallar, Kattankudi, Manmunai etc. Therefore, in terms of nitrate concentrations, aquatic organisms in the Batticaloa Lagoon could suffer due to existing nitrate concentration of the lagoon and the low level of dissolved oxygen.

\section{Spatial and temporal variations in phosphate}

The monthly mean values of phosphate in lagoon water ranged from 0.18 to $0.50 \mathrm{mg} / \mathrm{l}$. Fig. 6 illustrates the phosphate levels of Batticaloa Lagoon at different locations during one year period. The highest value was recorded during November 2012 at Puthukudiyruppu (L14).

The phosphate content varied in between 0.04 to $1.56 \mathrm{mg} / \mathrm{l}$; lowest concentration was obtained during July and October period. Phosphate concentration was found high in lagoon near urban and cultivation areas such as Puthukudiyruppu and Paddiruppu due to runoff from agricultural fields and settlements.

According to the CEA water quality standards for Sri Lanka as quoted by Green Tech Consultants (2009), the maximum permissible limit of phosphate concentration for aquatic life is $0.4 \mathrm{mg} / 1$ and the critical level for avoiding accelerated eutrophication is $0.1 \mathrm{mg} / \mathrm{l}$. However, the results obtained in this study revealed that the level of phosphate in many occasions exceeded this limit thus enhanced the eutrophication process in the lagoon. Due to the flushing nature of this lagoon the concentrations vary during dry and wet seasons.

The periodic eutrophication of Batticaloa Lagoon also was observed at the locations such as Puliyanthivu (L3), Eravur (L8), Urani (L4), Nochchimunai (L10), Kattankudy (L11), Manmunai (13) and Paddiruppu (L16). Agricultural run-off containing nutrient fertilizers from nearby farms and cultivated lands could have contributed to the increase in Phosphate in Batticaloa Lagoon. Thus, high concentration of these types of nutrients indicating that the mixing of anthropogenic inputs into the lagoon. Anthropogenic activities could influence the lagoon ecosystem and the environment and finally influence the dependant economic activities such as fishing, recreation, tourism, agriculture and the industries.

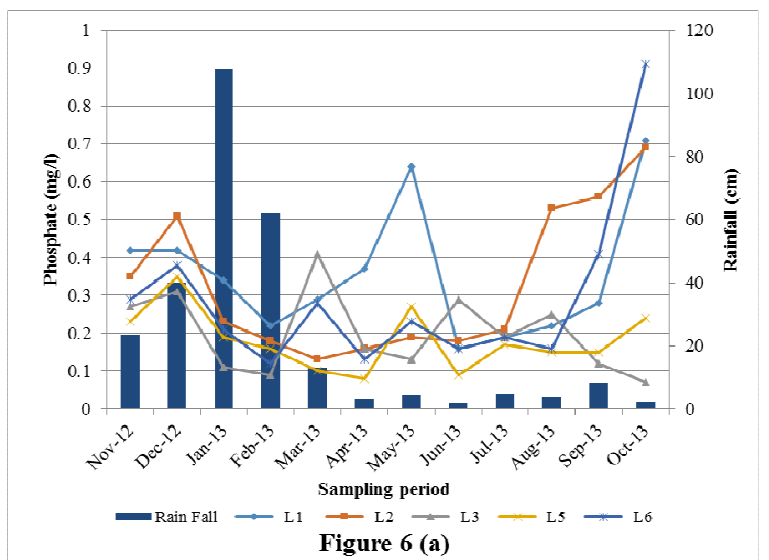



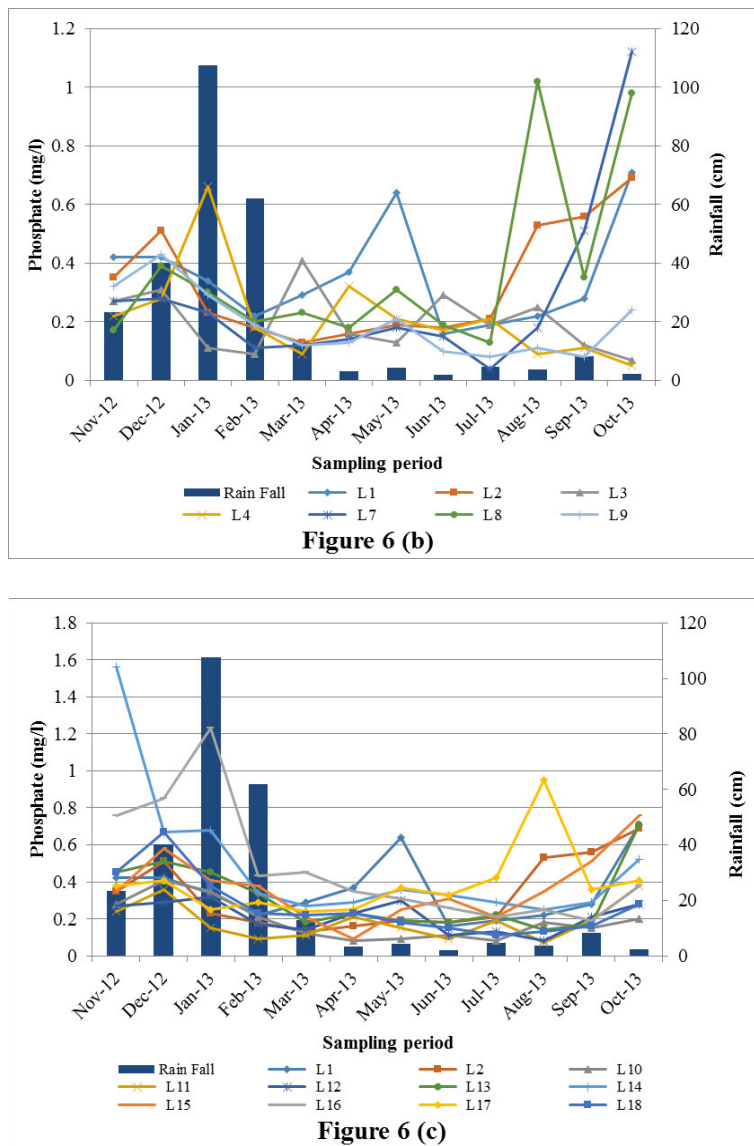

Fig. 6. Spatial and temporal variations of phosphate concentrations in Batticaloa Lagoon (a, b and $c$ are for west north and south directions, respectively)

\section{CONCLUSIONS}

In this study physico-chemical parameters of water at Batticaloa Lagoon were assessed. Salinity levels of the lagoon water were high at the later part of dry season. The variation was mainly due to the rainfall pattern in the region. Further, salinity of this coastal lagoon mainly comes from the saline water that flows from the ocean. Higher salinity levels as recorded in the areas closer to the sea are favourable for prawns. Due to seasonal distribution of rainfall, Batticaloa Lagoon experiences seasonal flooding which introduces a lot of suspended particles into the lagoon. Dissolved oxygen level of the lagoon water is favourable for aquatic species. Nitrate and phosphate concentrations of the lagoon closer to urban and cultivated areas exceeded the threshold limit considered for the aquatic species.

The results are important in understanding the pattern of variation of water quality parameters of the lagoon. Therefore, this information can be used to plan, protect and manage the lagoon water for different uses. It is proposed to investigate and model the influence of tidal action and barmouth opening on water quality (salinity in particular) so as 
to device an informed management strategy to manipulate the salinity by barmouth operations when the salinity levels are law.

\section{RECOMMENDATIONS}

Follow up research needs to be conducted for the determination of nutrient load from adjacent farm to the lagoon. Further, complete study on the effect of anthropogenic activities and natural processes on Batticaloa lagoon is necessary to make a water quality management plan for the Batticaloa Lagoon.

\section{ACKNOWLEDGEMENT}

This work was carried out with the aid of a grant from the HETC project, Ministry of Higher Education, Sri Lanka. Their financial support is greatly acknowledged.

\section{REFERENCES}

Abowei, J.F.N. (2010). Salinity, dissolved oxygen, pH and surface water temperature conditions in Nkoro River, Niger Delta, Nigeria. Adv. J. Food Sci. Technol., 2(1), 16 - 21.

Atasoy, M., Palmquist, R.B. and Phaneuf, D.J. (2006). Estimating the effects of urban residential development on water quality using microdata. J. Environ. Manage, 79, 399 - 408.

Banerjee, T.K (2008) Culture of fresh water nrawn· In Annlied 7onlnov First (F.d) Ranaras Hindı University Publisher: National science digital library (NSDL), CSIR, Govt. of India; $17-18$.

Bilotta, G.S. and Brazier, R.E. (2008). Understanding the influence of suspended solids on water quality and aquatic biota. Water Res. doi: 10/1016/j.watre.03.018.

Chandrasekara, C.M.K.N.K., Weerasinghe, K.D.N., Ranjana U K Piyadasa and Sumith Pathirana. (2014). Salinity, $\mathrm{pH}$ and Turbidity changes of water in the Negombo lagoon. Colombo Arts. Journal of Social Sciences and Humanities, 1-11.

Choi, K.S. and Blood, E. (1999). Modelling developed coastal watersheds with the agricultural non-point source model. Journal of the American Water Resources Association (JAWRA), 35, 233 - 244.

Furusato, E., Amarasekara, G.P., Priyadarshana, T. and Tanaka, N. (2012). The current status of density stratification of Koggala lagoon. ACEPS- 2012. 176 - 185.

Garnier, J., Billen. G., Sanchez, N. and Leporeq, B. (2000). Ecological functioning of the marine reservoir (Upper seine basin, France). Regul River, 16, 51-71.

Green Tech Consultants. (2009). An assessment of the change in shoreline location along the coast of the Eastern Province of Sri Lanka, using remote sensing technology. Revised Final Report. Pp. 49. North East Coastal Community Development Project (NECCDEP). 
James E. Cloern. (2001). Our evolving conceptual model of the coastal eutrophication problem: Review. Marine Ecology Progress Series, 210, 223 - 253.

Srinivasan K. and Natesan, U. (2013). Spatio-Temporal variations in water quality of Muttukadu Backwaters, Tamilnadu, India, Water Environ. Res. 85(7), 587 - 95.

Kara, Y., Kara, I. and Basaran, D. (2004). Investigation of some physical and chemical parameters of water in the Lake Lsykli in Denizli, Turkey. International J. Agriculture and Biol., 6(2), 275 - 277.

Lawson, E.O. (2011). Physico-Chemical Parameters and Heavy Metal Contents of Water from the Mangrove Swamps of Lagos Lagoon, Lagos, Nigeria. Advances in Biological Research, 5(1), 08 - 21.

NECCDEP. (2010). Batticaloa Lagoon Special Area Management Plan "BL SAM". Final. Pp. 125. January 2010. Eastern Province Integrated Coastal Resources Management Plan (EP ICRMP) 2010-2013. The Green Blue Sunrise Plan. Anzdec Ltd., Resource Development Consultants. ADB LOAN 2027 SRI (SF): North East Coastal Community Development Project (NECCDEP).

Sikora, W.B. and Kjerfve, B. (1985). Factors influencing the salinity of Lake Pontchartrain, Louisiana, a shallow coastal lagoon: analysis of a long-term data set. Estuaries, Coastal and Shelf Science, 8, 170 - 180.

Sugirtharan, M., Pathmarajah, S. and Mowjood, M.I.M. (2014a). Variation of salinity in Batticaloa lagoon in Sri Lanka during wet season. Tropical Agricultural Research Vol. 25 (3): 403 - 411 Post Graduate Institute of Agriculture, Sri Lanka.

Sugirtharan, M., Pathmarajah, S. and Mowjood, M.I.M. (2014b). Temporal Flux of Salinity and lagoon water height in Batticaloa Lagoon of Sri Lanka During dry Season. European International Journal of Applied Science and Technology Vol. 1 No. 5; p 150-163.

Suski, C.D., Killen, S.S., Keiffer, J.D. and Tufts, B.L. (2006). The influence of environmental temperature and oxygen concentration on the recovery of large mouth bass from exercise. Implications for live-release angling tournaments. J. Fish Biol., 68, 120 - 136.

USEPA (----) Secondary Drinking Water Standards: Guidance for Nuisance Chemicals [on line]. [Accessed on 16.06.2017] Available at https://www.epa.gov/dwstandardsregulations/secondary-drinking-water-standards-guidancenuisance-chemicals\#table

WHO. (2008). Guidelines for drinking water quality. 3rd Ed. Health criteria and supporting information, Geneva. 